\title{
Käytännöllisen tiedon luonne
}

Sarvimäki, Anneli 1989. Käytännöllisen tiedon luonne. Aikuiskasvatus 9, 2, 48-51.

- Artikkeli lähtee klassisesta tiedon määritelmästä, joka todetaan liian suppeaksi määrittelemään kaikkea tietoa. Käytännöllisillä aloilla tarvitaan laajempaa tietokäsitettä. Filosofian historiassa käytännöllistä tietoa ovat analysoineet $\mathrm{mm}$. Platon, Aristoteles, Vico ja Kant. Käytännöllinen kasvatustieto määritellään laajaksi yhteiskunnalliseksi ja moraaliseksi tiedoksi, johon sisältyy tekninen taito. Määritelmä pohjautuu näkemykseen kasvatuksesta moraalisena elämänmuotona. Käytännöllinen tieto on organisoitu toimintakaavoihin ja traditioihin ja se ilmenee adekvaattina toimintana.

Filosofisen tietoteorian kiinnostuksen kohteena on pitkälti ollut ns. klassinen tietokäsitys tai joku muunnelma siitä. Klassisen tietokäsityksen mukaan tieto on hyvinperusteltu tosi uskomus (Niiniluoto 1980, 138). Tämäntyyppisen tietokäsityksen muunnelmia ovat esim. spekulatiivinen tieto, teoreettinen tieto, analyyttinen tieto ja propositionaalinen tieto. Yhteistä näille kaikille on, että tieto ymmärretään uskomusjärjestelmänä, joka on yleensä ilmaistavissa käsitteiden ja lauseiden avulla.

Monella käytännöllisellä tiedonalueella on kuitenkin ollut nähtävissä pyrkimys laajentaa ja monipuolistaa tietokäsitystä. Niinpä esimerkiksi Wilenius (1976), Elbaz (1983) ja Brownhill (1983) ovat esittäneet ja puolustaneet näkemyksiä käytännöllisestä kasvatustiedosta. Hoito-opin piirissä Carper (1978) ja Benner (1984) ovat esittäneet samantapaisia ajatuksia.

\section{Käytännöllisen tieto- käsitteen historiaa}

Käytännöllinen tietokäsite ei ole filosofiassakaan uusi, vaikka se on viime vuosikymmenien aikoina ehkä jäänyt spekulatiivisen tietokäsitteen jalkoihin. Itse asiassa käytännöllisellä tietokäsitteellä oli tärkeä merkitys sekä Platonin että Aristoteleen tietoteoriassa.

Käsityöläisten taito muodosti sekä Platonille että Aristoteleelle tärkeän tietoihanteen. Platonin mukaan käsityöläisten valmistustaito sisälsi sekä teknistä taitoa että teoreettista tietoa: esimerkiksi lääkintätaito oli erottamattomasti nivoutunut lääkärin tietoon terveyden luonteesta. Oleellista tässä käytännöllisessä tietomuodossa on tieto tavoitteesta ja taito saavut- taa tavoite. Platonin mukaan on kuitenkin olemassa myös toinen käytännöllinen tietomuoto, jota on kutsuttu "käyttäjän tiedoksi". Käyttäjän tieto sisältää tietoa siitä, miten ja mihin käsityöläisen valmistama esine voidaan käyttää. Näin ollen tämä käytännöllinen tietomuoto on laajempi kuin valmistustaito - voidaan sanoa, että valmistaja työskentelee käyttäjän toimeksiannosta ja että käyttäjällä on syvällisempää tietoa esineen luonteesta ja mahdollisuuksista. Käyttäjän tietoon sisältyy myös eettisiä ulottuvuuksia ja tieto siitä yhteiskunnasta ja ympäristöstä, jossa esinettä aiotaan käyttää (Hintikka 1965; 1969, 21-27, 59-74; 1974, 1-47, 80-81).

Samantyyppinen erottelu esiintyy Aristoteleella, joka puhui toisaalta teknisestä taidosta, toisaalta käytännöllisestä tiedosta. Myös Aristoteleen jako erottaa toisistaan taidon saavuttaa tietty tavoite ja laajemman tiedon siitä, mitkä tavoitteet ovat hyviä ja tavoittelemisen arvoisia. Tämä laajempi käytännöllinen tieto on myös Aristoteleen käsitemaailmassa eettistä ja yhteiskunnallista. (Aristoteles 1967, 161-181).

Merkittäviä analyyseja käytännöllisestä tiedosta ovat filosofian historiassa esittäneet antiikin jälkeen mm. Giambattista Vico (1961) ja Immanuel Kant (1981) 1700-luvulla. Etenkin Kantin näkemyksessä erottuu samantapainen hierarkinen lähestymistapa kuin Platonilla ja Aristoteleella: tekninen taito ilmenee kyvyssä saavuttaa asetettuja tavoitteita kun taas käytännöllinen tieto on laajempi käsite, sisältäen moraalisen ulottuvuuden.

Yhteinen piirre kaikille käytännöllisille tietomuodoille - oli ne sitten teknisiä tai moraalisia - on kuitenkin se, että on kysymys tiedostá, joka ilmenee toiminnassa. Tämä piirre painottuu ainakin Platonin ja Aristoteleen käsityksissä, mitä myös Wilenius (1976) korostaa. 
Miten sitten kasvatustietoa tulisi ymmärtää? Onko kysymys teknisestä taidosta vai moraalisesta ja yhteiskunnallisesta tiedosta? Tässä voidaan todeta, että esimerkiksi Aristoteles ymmärsi kasvatustiedolla lähinnä teknistä taitoa "valmistaa" hyviä kansalaisia; politiikan tehtävänä taas on määritellä, mitä hyvällä kansalaisella tarkoitetaan (Taylor 1971, 85).

Tämän perustella olisi olemassa kahdentasoista käytännöllistä kasvatustietoa: toisaalta teknistä "valmistustaitoa", toisaalta moraalista ja yhteiskunnallista "käyttäjän tietoa". Yhdistettynä Platonin ja Aristoteleen edustamaan yhteiskunta- ja ihmiskäsitykseen tämä tarkoittaisi edelleen, että opettajilta ja kasvattajilta ei edellytettäisi laajempaa yhteiskunnallista ja moraalista tietoutta, vaan pelkästään teknistä taitoa. Tavoitteiden määritteleminen kuuluisi yksinomaan politiikoille, joiden toimeksiannosta opettajat työskentelisivät.

Tällainen käsitys käytännöllisestä kasvatustiedosta löytyy varmaan tänäänkin joidenkin kasvatustieteiliijöiden ja politiikkojen piirissä. On kuitenkin tärkeää todeta, että se, miten kasvatustiedon luonteeseen suhtautuu, on viime kädessä yhteydessä määrättyyn yhteiskunta- ja ihmiskäsitykseen. Se on myös yhteydessä siihen, miten kasvatuksen luonne ymmärretään.

Edellä esitetty näkemys perustuu siihen, että kasvatuksessa voitaisiin tehdä selkeä ero tavoitteiden ja välineiden välillä, jolloin tavoitteiden määritteleminen kuuluisi toiseen tietopiiriin ja toiselle yhteiskuntatasolle kuin välineiden valinta ja soveltaminen. Tämän tradition jatkajia kasvatustieteessä löytyy lähinnä positivistien piiristä. Positivisteillahan on taipumus erottaa toisistaan tavoitteet ja välineet, arvot ja tosiasiat (esim. Mill 1872, 546-553). Saksalainen kasvatustieteilijä Wolfgang Brezinka edustaa tämäntyyppistä ajattelua. Kasvattaminen on hänen mukaansa vaikuttamista niihin lainalaisuuksiin, jotka ohjaavat persoonallisuuden kehittymistä tiettyjen persoonallisuuspiirteiden aikaansaamiseksi (Brezinka 1976, 80, 106-111).

Toisenlaista näkemystä edustavat esimerkiksi englantilainen kasvatusfilosofi Richard Peters ja norjalainen kasvatustieteilijä Erling Dale. Petersin näkemyksen mukaan kasvatuksessa ei ole mahdollista erottaa toisistaan tavoitteita ja välineitä, arvoja ja tosiasioita; pikemminkin kasvatus pitäisi nähdä elämänmuodon oppimisena, jolloin kasvatusprosessi sinänsä edustaa tavoiteltavaa elämänmuotoa (Peters 1967, $5-9 ; 1970)$. Dale (1975) taas edustaa marxilais-habermasilaista traditiota; hän kuvaa kasvatusta dialogisena ja vapauttavana toimintana pikemmin kuin tavoitevälinetoimintana. Samantapaista ajattelua edustaa myös alunperin brasilialainen kasvatustieteilijä Paulo Freire (1973).

Petersin, Dalen ja Freiren näkemystä ei ole vaikeaa perustella. Kasvatus- ja koulutusprosessi on kiinteä osa sitä kulttuuria ja yhteiskuntaa, jossa se toimii. Kaikki se mitä koulutuksessa ja kasvatuksessa tapahtuu on arvojen läpäisemää: ei ole olemassa "neutraaleja" välineitä eikä keinoja, jotka johtaisivat "hyviin" tavoitteisiin. Jos esimerkiksi halutaan kasvattaa demokraattisia kansalaisia, demokraattisten arvojen täytyy heijastua myös itse kasvatusprosessiin. Näin ollen kasvatus voitaisiin ymmärtää moraaliseksi elämänmuodoksi. Kasvatus elämänmuotona tarkoittaa sitä, että kasvattaminen ja kasvaminen on elämistä - ei pelkästään erilaisten keinojen avulla vaikuttamista toisen ihmisen kehitykseen. Kasvavan kannalta se on myös aktiivista kokeilua ja etsimistä, oivallusten ja virheiden tekemistä. Kasvatustilanne on osa elävää elämää, johon kuuluvat kaikki elämän perusainekset: riemua ja pettymystä, surua ja iloa, yhdessäoloa, ystävyyttä ja yksinäisyyttä, ponnistelua, ahdistusta, menestystä. Näiden kokemusten kautta ihminen kasvaa. Kasvatus moraalisena elämänmuotona tarkoittaa, että kasvatuksessa on pohjimmiltaan kysymys hyvästä elämästä ja sen edistämisestä. Kasvatuksen pitäisi toisaalta edistää, toisaalta edustaa hyvää elämää (Ks. myös Sarvimäki $1986 \mathrm{a}, 1986 \mathrm{~b}, 32-35$, 136-140 ja 1988, 79-88).

Tämä tarkoittaa sitä, että käytännöllistä kasvatustietoa ei voida ymmärtää pelkkänä teknisenä taitona saavuttaa toisten asettamia tavoitteita. Käytännöllinen kasvatustieto edustaa pikemminkin Aristoteleen tarkoittamaa praktista tietoa, t.s. se on pohjimmiltaan moraalista ja yhteiskunnallista. Käytännöllinen kasvatustieto voi - ja varmasti sen pitääkin - sisältää teknistä taitoa, mutta teknisiä taitoja tulee aina soveltaa osana moraalista elämänmuotoa. Tämä tarkoittaa myös sitä, että mikäli opettaja haluaa olla praktikko eikä pelkkä teknikko, häneltä edellytetään teknisten taitojen ohella myös moraalista ja yhteiskunnallista tietoutta.

\section{Käytännöllisen tiedon organisointi}

Tähänastisen esityksen perusteella käytännöllistä kasvatustietoa voidaan luonnehtia moraalisena ja yhteiskunnallisena tietona, joka sisältää teknisiä taitoja ja joka ilmenee toiminnassa.

Käytännölliseen tietoon liittyy kuitenkin muitakin luonteenomaisia piirteitä. Käytännöllinen tieto ilmenee toiminnassa, mutta se on 
myös muissa suhteissa kiinteästi sidottu toimintaan. Voidaan sanoa, että käytännöllinen tieto on organisoitu toimintaan, opitaan toimimalla ja välittyy toiminnan kautta.

Käytännöllisen tiedon rakennetta ja organisointia ovat analysoineet $\mathrm{mm}$. Michal Polanyi (1958), Jean Piaget (1971, 6-8, 268-345), P.J. Galperin (1979, 59-88), Ulric Neisser (1982, 24-27, 46-66), Donald Schön (1983, 50-69) ja David Hunt (1987, 1-3, 58-81). Yhteistä näille tutkijoille on se, että he näkevät käytännöllisen tiedon organisoituna erityyppisiin toimintakaavoihin: implisiittisiin teorioihin, skeemoihin jne. Nämä organisoivat toimivan henkilön arvoja, uskomuksia ja taitoja toimintakaavoihin, jotka ohjaavat toimintaa. Mikäli toiminta on tilanteeseen nähden adekvaattia ja sopivaa, toimintakaava sisältää käytännöllistä tietoa. Mikäli toiminta on tilanteeseen nähden epäadekvaattia ja sopimatonta, toimintakaava sisältää käytännöllistä tietämättömyyttä. Tieto, joka on organisoitu toimintakaavoihin ja joka ilmenee adekvaattina toimintana ei välttämättä ole ilmaistavissa käsitteiden ja lausekkeiden avulla. Näin ollen henkilö saattaa toimintansa kautta ilmaista enemmän tietoa kuin mitä hän pystyy sanallisesti ilmaisemaan. Osa toimintakaavoihin organisoidusta tiedosta saattaa periaatteessa olla mahdollista pukea käsitteisiin ja lauseisiin. Näin eksplisiittiseksi artikuloitu tieto voi sitten toimia tietoisena toimintaperustana. Sen avulla ihminen analysoi toimintatilannetta, laatii suunnitelmia ja arvioi toimintansa seurauksia. Toisaalta saattaa myös olla niin, että osaa käytännöllisestä tiedosta ei ole ollenkaan mahdollista artikuloida. Tällaisia artikuloimattomia elementtejä saattavat olla esimerkiksi intuitioon perustuva tieto, tunteisiin ja fysiologisiin reaktioihin perustuvat elementit, käden taidot ja tuttavuus (Ks. myös Sarvimäki 1988, 120-155).

Käytännöllisen tiedon oppimisessa ja välittämisessä traditiolla on tärkeä merkitys. Tradition merkitystä on tuonut esiin ennen muita Polanyi (1958, 49-65). Tietyn käytännöllisen toiminnan oppiminen - esimerkiksi opettaminen ja kasvattamisen oppiminen - merkitsee alan traditioon kasvamista. Traditiota voidaan ymmärtää kollektiivisella tasolla organisoituna toimintakaavoina, jotka pitkälti ohjaavat ammattiryhmän toimintaa. Traditio sisältää edellisten ammattisukupolvien kautta kerääntynyttä tietoa - tai tietämättömyyttä. Jos traditio kuolee, kuolee myös sen sisältämä tieto. Kun traditioon sisältyvät toimintamuodot eivät enää ole adekvaatteja - maailman muuttumisesta johtuen - täytyy traditiota kritisoida ja uudistaa (ks. myös Nerman 1982, 120 ja Sarvimäki 1988, 169-175).

Käytännöllinen tieto voi olla myös organisoituneena eri tasoille. Käytännöllisen tiedon eri tasoja ovat kuvanneet Stuart ja Hubert Dreyfus, joihin mm. Patricia Benner (1984) viittaa omassa tutkimuksessaan. Näissä tutkimuksissa kuvataan käytännöllisen tiedon viisi tasoa noviisista asiantuntijaan. Alemmilla tasoilla toimivalla henkilöllä ei ole juurikaan vaihtoehtoja toiminnoilleen, toiminta on kankeaa, mallien ja ohjeiden säätelemää. Ylemmillä tasoilla toimiva henkilö sen sijaan toimii enemmän oman kokemuksensa varassa, käyttää intuitiotaan ja pysyy nopeasti erottamaan toimintatilanteen oleelliset piirteet epäoleellisista.

\section{Lopuksi}

Esitettyjen ajatusten pohjalta voidaan todeta, että klassinen tiedon määritelmä ei riitä määrittelemään kaikkea mahdollista tietoa. Tietoa ei ole organisoitu ainoastaan uskomusjärjestelmiin, vaan myös toimintakaavoihin, implisiittisiin teorioihin, traditioihin ja taitoihin.

Käytännöllisellä tietokäsitteellä on relevanssia usealla koulutus- ja kasvatusalalla. Varsinkin ammatillisen koulutuksen piirišsä toimivat kouluttajat voisivat hyödyntää tämän tietokäsitteen analyysiä. Tämä koskee luonnollisesti myös niitä kouluttajia, jotka opettavat tulevia kasvattajia ja kouluttajia.

Mikäli analyysia halutaan viedä vielä pitemmälle, voidaan jopa väittää, että käytännöllisen tiedon idea on primaarisempi kuin teoreettisen tiedon käsite ja että käytännöllisen tiedon ymmärtämistä näin ollen voitaisiin pitää edellytyksenä teoreettisen tiedon ymmärtämiselle.

\section{Kirjallisuus}

Aristoteles. 1967. Den nikomachiska etiken. Helsingfors: Holger Schildt.

Benner, P. 1984. From novice to expert. Excellence and power in clinical nursing practice. Ca., Menlo Park: Addison Wesley Publ. Co.

Brezinka, W. 1976. Erziehungsziele, Erziehungsmittel, Erziehungserfolg. München: Emst Reinhardt Verlag.

Brownhill, R. 1983. Education and the nature of knowledge. London: Groom Helm.

Carper, B. 1978. Fundamental pattes of knowing in nursing. Advances in Nursing Science, Vol. 1, No. 1, 13-23.

Dale, E. 1975. Inledning till dialektisk pedagogik/Pedagogisk kritik. Stockholm: Bo Cavefors.

Elbaz, F. 1983. Teacher thinking. A study of practical knowledge. London: Croom Helm.

Freire, P. 1972. Pedagogik för förtryckta. Stockholm: Gummessons. 
Galperin, R.J. 1979. Johdatus psykologiaan. Helsinki: Kansankulttuuri.

Hintikka, J. 1965. Tieto, taito ja päämäärä. Kaksi tutkielmaa vanhojen kreikkalaisten tiedonkäsityksestä. Ajatus, Vol. XXVII, 49-67.

Hintikka, J. 1969. Tieto on valtaa. Porvoo: WSOY.

Hintikka, J. 1974. Knowledge and the known. Dordrecht, Holland: D. Reidel Publishing Company.

Hunt, D. 1987. Beginning with ourselves in practice, theory and human affairs. Cambridge, Ma.: Brookline Books.

Kant, I. 1981. Grounding for the metaphysics of morals. Indianapolis, Cambrindge: Hackett Publishing Co.

Mill, J.S. 1872. System of Logic, Vol. 2. London: Longmans, Green, Reader and Dyer.

Neisser, U. 1982. Kongnitio ja todellisuus. Espoo: Weilin \& Göös.

Nerman, B. 1982. Om erfarenheten. En studie i skapandets villkor. Stockholm: Bonniers.

Niiniluoto, I. 1980. Johdatus tieteenfilosofiaan. Helsinki: Otava.

Peters, R. 1967. What is an educational process? in: Peters, R. (Ed.) The concept of education. London: Routledge \& Kegan Paul.
Peters, R. 1970. Must an educator have an aim? in: Cahn, S. (Ed.) The philosophical foundations of education. New York: Harper \& Row.

Piaget, J. 1971. Biology and knowledge. Edinburgh: Edinburgh University Press.

Polanyi, M. 1958. Personal knowledge. Chicago: The University of Chicago Press.

Sarvimäki, A. 1986a. Kasvatustoiminta - kommunikatiivista vuorovaikutusta ja luovaa yhteistoimintaa. Aikuiskasvatus, No.4, 168-172.

Sarvimäki, A. 1986b. Skapande interaktion. Forskningar $\mathrm{nr}$ 10. Helsingfors svenska sjukvårdinstitut.

Sarvimäki, A. 1988. Knowledge in interactive practice disciplines. Research Bulletin 68 . Department of Education, University of Helsinki.

Schön, D. 1983. The reflective practitioner. New York: Basic Books.

Taylor, A. 1971. Aristoteles. Stockholm: Natur och Kultur.

Vico, G. 1961. The new science. New York: Anchor Books.

Wilenius, R. 1976. Kasvatuksen ehdot. Jyväskylä: Gummerus. 


\section{AIKUISKASVATUS \\ The Finnish Journal of Adult Education \\ Vol. 9,2/89 \\ ISSN 0358-6197 \\ Summary}

Sarvimäki, Anneli 1989. The nature of practıcal knowledge. Aikuiskasvatus 9, 2.

The author begins by referring to the classical definition of knowledge and finds it too restricted for defining all knowledge. A more extensive concept of knowledge is needed in practical fields. Practical knowledge has in the history of philosophy been dealt with by Platon, Aristotle, Vico and Kant to name a few. Practical educational knowledge is defined as extensive social and moral knowledge which includes technical skill. This definition is based on education as a moral form of life. Practical knowledge is organized into action formulas and traditions and it makes itself apafter the courses. 